Nurseitova L., Balgimbayeva N.

The emergence of the yokai concept in japanese culture

Нурсеитова А., Балгимбаева Н.

Жапон мәдениетінде «Ёкай» түсінігінің пайда болуы

Нурсеитова ^., Балгимбаева Н.

Появление концепта «Ёкай» в японской культуре
The article is dedicated to the concept of yokai, namely to its emergence in Japanese culture and further development. According to the author, the issue of supernatural beings in Japanese culture is of great importance in terms of both understanding mentality, psychology of Japanese people and studying the language and the history of this country.

Key words: Mystical, religious, yokai, emergence, demon, ritual, traditional, supernatural, dramatic, phenomenon.

Бұл мақалада автор «ёкай» концепциясының жапон мәдениетінде пайда болып, дамуын қарастырған. Автордың айтуы бойынша, жапон мәдениетіндегі табиғаттан тыс күштер мәселесі арқылы жапон менталитетін, психологиясын, тілін, тарихын түсінуге болады.

Түйін сөздер: мистикалық, Аіни, ёкаи, пайда болуы, жын немесе перілер, салт-жоралар, Аәстүрлі, драматикалық, құбылыс.

Статья посвящена концепции «ёкай», а именно её появлению в рамках японской культуры и Аальнейшему развитию. По словам авторов, проблема сверхъестественных существ в японской культуре невероятно важна не только Аля понимания менталитета и психологии японского народа, но и Аля изучения языка и истории этой страны.

Ключевые слова: мистический, религиозный, ёкаи, появление, Аемон, ритуал, традиционный, сверхъестественный, Араматический, явление. 


\section{THE EMERGENCE OF THE YOKAI CONCEPT IN JAPANESE CULTURE}

Mystical, supernatural and inexplicable phenomena have always been an essential part of Japanese culture. Due to the existence of complex religious beliefs and a lifestyle proclaiming nature as sacred, a large array of new images began to evolve in people's mind. Probably one of the best examples illustrating this fact is the emergence of the yokai concept in Japanese culture.

Basically, a word «yokai» (妖怪) is a collective term for such things as ghosts, goblins, monsters and other evil spirits. The term itself consists of two kanjis: 妖 («уо») stands for «magical, enchanting» and 怪 which means «mysterious», «strange». It is also important to mention that there is no exact translation of the term into any other language because of its originality and self-sufficiency. The world of Japanese supernatural creatures is vast enough: there are more interesting concepts than just one. For instance, such concepts as «yurei» (malicious and vindictive spirits of passed away people as a rule), «kami» (deities mostly known as a main Shinto concept), «bakemono» (monsters resembling animals) are objects of a great interest for researchers.

According to Yanagita Kunio (often known as the father of Japanese native folkloristics), fears are laying in the basis of human nature, and gradually transforming, cause the emergence of diverse monsters [1]. Primeval culture based on fear existed in the history of Japanese culture is key to understand changes in Japanese people's outlook, their beliefs and religion. Yanagita's research on monsters has assuredly helped to solve a complicated puzzle of Japanese perception and society changes.

The moment when Japanese culture got acquainted with supernatural beings dates back to high antiquity. Probably the most popular representative of the yokai family, a Japanese demon (oni), is mentioned in the work called «Izumo-no Kuni Fudoki» («The Historical and Geographical Description of the Izumo Province») written in 733 (The Tempyo period). Nevertheless, it is a fact that oni of that period looked completely different from oni we know today. It is widely believed that the word «oni» originated from the kanji meaning «to conceal», «to hide», which leads us to an assumption that ancient oni could not be seen by a person, nor they had a concrete form, but still they were something to be afraid of. 
Actually, everything strange and inexplicable was originally named «yokai». In fact, Ancient Japan was literally chaotic when it comes to material and social state of affairs. All the phenomena and events which could not be accurately explained by human intellect were called yokai, in spite of the fact that the term itself began spreading only after the Meiji era. Usually, strange beings had an unusual form, different from a human body, and possessed a multitude of incredible magical powers and abilities. Moreover, there were specific forms of yokai without a certain form, which were believed to be a source of evil and fear, they could even cause troubles and harm to people. A strong belief in yokai's ability to feel as genuinely as human beings undoubtedly came from folktales about living rivers, mountains, stones, not to mention animals. While trying to find answers to their questions regarding the nature of yokai, people came to this conclusion: at times a soul of a person who has harbored malice and grievance deep inside of his/her heart, is potentially able to come back to the world of living and to take revenge. A very good verification of this idea is an ancient legend about the giant serpent Yamata-no Orochi mentioned in the notable literary work «Nihon Shoki». Not only has this very legend acknowledged the fact of existence of yokai in the minds of ancient Japanese people, but it has also showed how aware people were of natural phenomena as well. An uncanny and terrifying image of the monster made people be truly scared of nature and warned about the destructive power of mountain, stone and river spirits. According to the legend, not only nature can bring disasters and misfortune, but also human flaws and vices such as rancor, envy, vindictiveness, disobedience to the Emperor court.

Middle Ages have noticeably defined the further avenue for supernatural themes development, especially within the framework of art: starting from the XI century the handscrolls called «emakimono» began becoming more popular. In most cases they illustrated different works (novels and other texts), sometimes a piece of the text itself was applied to the scroll. It was a time of significant changes in appearance of yokai: former invisible creatures finally obtained their form. The artistical aspect of emakimono definitely played an important role in creating a final look of monsters which had appeared long before the invention of scrolls. From the Heian period until the Kamakura period a totally new concept emerged: many collections of stories such as «Konjaku Monogatari» and «Ujishui Monogatari» referred to the term «hyakki yako» (百鬼夜行) literally meaning «a night parade of one hundred de- mons». The point of this concept was to picture terrifying malicious demons that were strolling around desolate streets at night and looking for a prey to feed on. The hyakki yako tendency was mainly concentrated on such yokai as oni (demons) and tengu - a creature looking like an abnormally tall man, usually with a red face and a long nose, at times it had wings and was dressed like a mountain hermit. As folklore and art were transforming, new images and forms appeared. A piece of art called «Hyakki Yako Emaki» by Tosa Mitsunobu (now it is in Sinjuan of the Daitokuji Shrine) is a perfect example of these changes (The Muromachi era). It is said that this work is one of the oldest scrolls of Japan, its artistical importance is invaluable in terms of both traditional art and the history of the country as well. This very scroll inspired the whole new generation of artists, willing to picture a terrifying and mysterious world of yokai. Toriyama Sekien, a famous art and graphics genius of Edo, derived inspiration from the above mentioned «Hyakki Yako Emaki».

Another prominent feature of middle ages folklore connected with supernatural creatures was a term «tsukumogami». The word meant animated household items which could turn out to be the result of magical animals' mischief (foxes or badgers were first in this list). Cunning animals usually were able to turn into any «normal» for a human being object, in most cases to deceive and give a lesson. Another important point about tsukumogami is that it often referred to quite old items. The people of Muromachi believed in a large array of prejudices: there was an assumption that all the household items that were more than a hundred years old could easily become possessed by a malicious spirit willing to harm people. Tsukumogami creatures also took part in the night parades (hyakki yako emaki) and were especially dangerous after being thrown away by their former owners. In some cases, these strange objects even wanted to consume their human prey [2, 7-34 ].

The basis of this kind of beliefs was a traditional Japanese religion called Shinto, the main postulate of which proclaimed everything around human beings to possess a soul and be treated with respect, thus the oldest objects were believed to be sacred and magical. The ritual of Susuharai or New Year Cleaning proves this connection to the concept of tsukumogami. It is a perfect time for ensuring the items in one's possession are properly cleaned and serviced $[3,105]$. The theme of tsukumogami was one of the most popular throughout the whole Muromachi period. Some of works were dedicated to them: «Tsukumoshinki» and «Tsukumogami Emaki». 
Meanwhile, Japan was facing some dramatic changes. It is known that the Edo period was a time of rapid growth of cities and urban culture development. New art genres and forms have evolved; first examples of printed books were out for sale - all of these factors positively influenced on folklore works, that is why this was the glorious era of yokai popularity. Printed copies of different works were rapidly spread among people; the newest technologies gave an opportunity to enjoy reading text and looking at illustrations in colors. One of the greatest works of that time was created by Toriyama Sekien (the representative of the Kano school of painting) called «Gazu Hyakki Yako». Each page of this work was dedicated to one specific yokai and contained a picture of it. The composition is also known as «the encyclopedia of yokai». Another 3 works by Toriyama Sekien completed the gallery of yokai images and made the author famous beyond Japan. Colorful woodblock prints and paintings called nishiki-e popularized the concept of yokai; the main point of them was to entertain readers, in this way yokai gradually became the objects of fun rather than terror.

The development of a commercial economy in Edo caused enhanced communication and brought urban ideas and progress to rural areas and vice versa. It meant that a variety of stories were told by merchants and artists travelling around the country. In most cases, these were elements of Japanese myths and legends, sometimes stories originated from classical Chinese texts. For instance, they were often used as impressions which could keep people awake all the night to perform rituals like koshinmachi (a nightlong vigil during which no one should sleep) $[4,79]$. Against the backdrop of growing popularity of storytelling during the Edo period, a new form of stories emerged. The term «kaidan» meaning «a narrative of strange things» turned out to be exceptionally popular among fans of storytelling. Although the term existed before the above mentioned time, it started being used in documents after the XVII century. In general, kaidan stories were mainly concentrated on supernatural phenomena, but nowadays strange and unusual stories are also included in this category.

Furthermore, strange and mystical stories soon brought new ideas to the art of kabuki. A play «Tokaido Yotsuya Kaidan» written by Tsuruya Nanboku IV is a classical kabuki play, which is an amalgamation of traditional Japanese beliefs in ghosts, karma and revenge.
Kaidan stories definitely had their impact on the whole world of yokai. Many of antagonists of these stories are now the most prominent yokai of all times. A book by Lafcadio Hearn «Kwaidan: Stories and Studies of Strange Things» consists of the stories collected by the author himself; one of the stories «Yuki-onna» describes a beautiful woman all in white appearing on cold winter nights, she also can transform into snow or mist, she is also able to kill with her frosty breath. This image is still being used by anime, manga and games authors. For instance, a famous Japanese manga and anime series «Nurarihyon no Mago» has a character that looks like a modern and younger version of Yuki-onna: this girl is cheerful and cute; she is wearing a scarf over her furisode (a type of kimono with long sleeves) [5].

The previous example shows us how positions regarding yokai have changed over all the centuries. Popular culture has transformed yokai into friendly, cute and demanded category of creatures: children want to watch programs about them, representatives of otaku culture buy merchandise with favorite yokai characters, and video game fans can spend hours playing games dedicated to demons and spirits.

But why yokai are treated with exclusive respect, why do Japanese people do not alienate themselves from the world of supernatural? The answer can be found in peculiarities of the Japanese perception of the world. According to Snitko, «Japanese culture is culture of understanding»: instead of researching the world and defining a subject and an object of this research, Japanese people believe they are an essential part of the world; in other words, it is impossible to understand the world around us by contradistinguishing $[6,123]$.

It is truly interesting how Japanese religious beliefs and traditions could not hinder a spreading demand for the yokai phenomenon, although it covers such serious concepts like death, fear and supernatural. On the contrary, it seems like everything mysterious entertains both adults and children: contemporary urban scary stories about yokai are still incredibly popular. The twentieth century gave us new reasons to be scared and fascinated by vivid images of Kuchisake-onna or Hanako-san. We believe that in future the concept of yokai will still be relevant as it is now, because we suppose that no other field of research can combine ethnical, spiritual, psychological and traditional elements as the yokai concept does. 


\section{References}

1 Oouchiyamashyouko «Kami to Youkai yanagitakunio Youkaidangi no naka de katarareru obake (dai 3 kai kokusai nihongaku konsoushiamu)». - Japan, 2009. - 1 p.

2 Lillehoj, Elizabeth. Transfiguration: Man-Made Objects as Demons in Japanese Scrolls. Asian Folklore Studies. 1995; 54(1): 7-34 p.

3 Yoda H, Alt M. Yokai Attack! The Japanese Monster Survival Guide. Tuttle Publishing. 2012: 105 p.

4 T. Reider, Noriko. The Emergence of Kaidan-shu: The collection of tales of the strange and mysterious in the Edo period. Asian Folklore Studies. 2001; 60(1):79 p.

5 «Tsurara Oikawa». Nurarihyon No Mago Wiki. February 7, $2016<\mathrm{http}: / /$ nurarihyonnomago.wikia.com/wiki/Tsurara_Oikawa>

6 Gerasimova, M.P. Main Features of Japanese Artistic Culture. Япония. Ежегодник. 2011; 40:110-123 c.

7 Edo no youkai: DIA Collection.Kabushikigaishya Daiyapuresu. 2015, 6-9 p.

\section{Литература}

1 Oouchiyamashyouko «Kami to Youkai yanagitakunio Youkaidangi no naka de katarareru obake (dai 3 kai kokusai nihongaku konsoushiamu)». - Japan, 2009. - 1p.

2 Lillehoj, Elizabeth. Transfiguration: Man-Made Objects as Demons in Japanese Scrolls. Asian Folklore Studies. 1995; 54(1):7-34 p.

3 Yoda H, Alt M. Yokai Attack! The Japanese Monster Survival Guide. Tuttle Publishing. 2012:105 p.

4 T. Reider, Noriko. The Emergence of Kaidan-shu: The collection of tales of the strange and mysterious in the Edo period. Asian Folklore Studies. 2001; 60(1):79 p.

5 «Tsurara Oikawa». Nurarihyon No Mago Wiki. February 7, $2016<$ http://nurarihyonnomago.wikia.com/wiki/Tsurara_Oikawa>

6 Gerasimova, M.P. Main Features of Japanese Artistic Culture. Япония. Ежегодник. 2011; 40:110-123 c.

7 Edo no youkai: DIA Collection.Kabushikigaishya Daiyapuresu. 2015, 6-9 p. 